\title{
PENGARUH VARIASI MEDIA PENDINGIN PADA PROSES PENGELASAN GMAW TERHADAP KEKERASAN DAN KETANGGUHAN BAJA AISI 1045
}

\author{
Alvin Ardian Pradana*, Carsoni, Hisyam Ma'mun \\ Jurusan Teknik Mesin, Universitas PGRI Semarang \\ Jl. Sidodadi Timur No. 24 Kota Semarang, 50232 \\ Email: alvin.pradana090498@gmail.com
}

\begin{abstract}
Abstrak
Perkembangan ilmu pengetahuan dan teknologi yang begitu pesat mendorong berkembangnya dunia industri dan tidak dapat dipisahkan dengan proses pengelasan. Pengelasan merupakan teknik menyambung dua logam atau lebih dengan memanfaatkan energi panas untuk mencairkan logam induk. Dalam pengelasan banyak faktor yang mempengaruhi salah satunya adalah proses quenching. Proses quenching proses dimana baja AISI 1045 yang termasuk baja karbon sedang mendapatkan perlakuan panas dengan suhu $830^{\circ} \mathrm{C}$ kemudian dilakukan pendinginan secara cepat dengan media pendingin. Tujuan dalam penelitian ini adalah untuk mengetahui pengaruh media pendingin dalam proses quenching baja AISI 1045. Metode yang digunakan dalam penelitian adalah eksperimen. Dalam penelitian yang dilakukan oleh penulis didapat nilai ketangguhan yang diperoleh dari media quenching udara sebesar $2.88 \mathrm{Joule} / \mathrm{mm}^{2}$, oli sebesar $1.25 \mathrm{Joule} / \mathrm{mm}^{2}$, solar sebesar $1.23 \mathrm{Joule} / \mathrm{mm}^{2}$, air sebesar $0.63 \mathrm{Joule} / \mathrm{mm}^{2}$, dan yang terendah adalah air garam sebesar $0.59 \mathrm{Joule} / \mathrm{mm}^{2}$. Sedangkan nilai kekerasan yang diperoleh dari media quenching air garam sebesar 62.47 HRC, air sebesar 56.67 HRC, solar sebesar 52.43 HRC, oli sebesar 49.1 HRC dan yang terendah yaitu udara 43.2 HRC. Dari hasil pengujian yang telah dilakukan dapat disimpulkan bahwa spesimen yang di lakukan quenching dengan media yang memiliki massa jenis rendah maka laju pendinginannya lambat dan berpengaruh pada nilai ketangguhan yang tinggi namun nilai kekerasan rendah begitu juga sebaliknya.
\end{abstract}

Kata Kunci : GMAW, kekerasan, quenching, uji ketangguhan

\section{PENDAHULUAN}

Seiring dengan berkembangnya dunia industri yang semakin maju khususnya di bidang konstruksi tidak dapat dipisahkan dari proses pengelasan karena memegang peranan utama dalam rekayasa dan reparasi produksi logam. Hal itu karena proses pengelasan adalah salah satu sarana untuk mencapai ekonomi pembuatan yang lebih baik. Pengelasan (welding) adalah teknik penyambungan logam dengan cara mencairkan sebagian logam induk dan logam pengisi dengan atau tanpa penambah dan menghasilkan logam kontinyu (Siswanto, 2011). Lingkup penggunaan pengelasan di bidang konstruksi maupun industri seperti pembuatan atau perbaikan jembatan, komponen mesin, boiler, kerangka transportasi, rangka bangunan baja, pipa minyak, rel kereta api, dan lain sebagainya.

Dalam dunia industri ada banyak jenisjenis pengelasan yang digunakan dan semuanya memiliki banyak kelebihan serta kekurangan. Untuk memilih jenis las yang akan dipakai untuk melakukan pengelasan tergantung oleh material yang akan dilas dan sesuai kebutuhan. Salah satu jenis pengelasan yang sering digunakan adalah pengelasan GMAW (Priyanto, 2017). Selain GMAW ada beberapa jenis pengelasan yang lainnya yaitu GTAW (Gas Tungsten Arc Welding), FCAW (flux cored arc welding), OAW (oxygen actylene welding) dan lain sebagainya (Wiryosumarto \& Okumura, 2008).

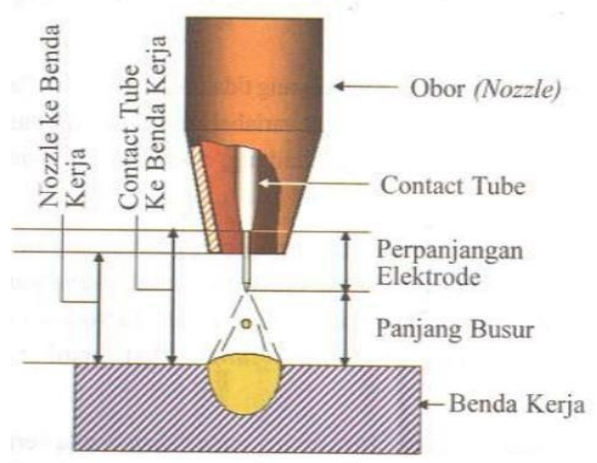

Gambar 1. Las GMAW

(Widharto, 2007) 
Pengelasan GMAW mempunyai beberapa kekurangan seperti adanya Busur tidak stabil, set up pada mesin las harus lebih detail supaya hasilnya baik serta memperhatikan gas pelindung agar tidak terjadi porosity. Kekuatan baja yang telah dilas dapat ditingkatkan dengan melakukan perlakuan panas terhadap baja tersebut (Duniawan, 2014).

Perlakuan panas atau heat treatment merupakan suatu proses kombinasi antara proses pemanasan dan pendinginan suatu logam untuk menghasilkan sifat-sifat tertentu dari logam tersebut. Perlakuan panas dengan metode quenching yaitu suatu proses pemanasan suatu logam atau baja sampai pada temperatur Austenite kemudian didinginkan secara cepat sehingga akan menghasilkan kekerasan yang lebih tinggi namun memiliki ketangguhan yang rendah. Pada proses quenching telah terjadi suatu perpindahan panas dari baja yang dipanaskan ke fluida pendingin yang digunakan, dengan kecepatan dan temperatur tertentu akan menghasilkan sifat mekanik pada logam tersebut (Yusman, 2018). Heat treatment merupakan suatu proses perlakuan panas dan pendinginan pada logam dilakukan secara terkontrol yang bertujuan merubah sifat mekanik pada logam (Purwanto, 2011). quenching adalah proses perlakuan panas dimana prosesnya dilakukan dengan pendinginan yang reaktif cepat dari temperature austenisasi (umumnya pada temperatur $815^{\circ} \mathrm{C}-870^{\circ} \mathrm{C}$ (Sultoni dkk., 2020).

Pengujian yang sering digunakan adalah pengujian kekerasan metode Rockwell karena mempunyai beberapa keunggulan dibandingkan metode yang lainnya yaitu lebih cepat dan tidak merusak sifat mekanik pada logam karena memiliki titik relatif kecil serta tidak memerlukan bantuan mikroskop untuk angka menentukan kekerasan pada logam. Selain itu, hasil dari pengujian Rockwell langsung muncul pada layar sehingga lebih mempermudah dan mempercepat dalam pengujian kekerasan suatu material dengan metode ini. Namun, hasil yang didapatkan dalam pengujian Rockwell ini kurang efektif dibandingkan dengan metode yang lainnya. Pengujian kekerasan metode Rockwell menggunakan 2 macam indentor yaitu indentor baja dan kerucut intan.
Penggunaan indentor dalam pengujian tergantung pada material yang akan diuji.

Pengujian impak digunakan untuk mengetahui angka ketangguhan pada logam. Menurut (Dieter, 1988) hasil dari pengujian impak tidak dapat terbaca secara langsung kondisi perpatahan batang uji, sebab tidak dapat mengukur komponen gaya- gaya tegangan tiga dimensi yang terjadi pada batang uji. Pengujian memiliki dua metode yaitu Charpy dan Izod.

Berdasarkan uraian latar belakang masalah di atas, maka identifikasi masalah dalam penelitian ini adalah pengaruh variasi media pendingin saat proses quenching pada baja AISI 1045 menggunakan proses pengelasan GMAW. Tujuan dari penelitian ini adalah untuk mengetahui pengaruh variasi media pendingin pada proses pengelasan GWAW terhadap kekerasan dan ketangguhan baja AISI 1045.

\section{METODOLOGI}

Material yang digunakan dalam pengujian ini adalah jenis baja AISI 1045. Material ini dilakukan pengelasan dengan menggunakan GMAW kemudian diberikan perlakuan heat treatment dengan proses quenching. Media pendingin yang digunakan dalam penelitian ini air garam, solar, Oli, air dan udara. Pengujian ini diawali dengan proses pengelasan GMAW di PT Idola Aerindo Udaya, selanjutnya untuk proses heat treatment dilakukan di Laboratorium dan workshop Teknik Mesin, Fakultas Teknik, Universitas Wahid Hasyim sedangkan untuk pengujian impak dan Rockwell menggunakan indentor baja 1/16". dilakukan di Laboratorium Teknik Mesin Universitas PGRI Semarang.

\section{HASIL DAN PEMBAHASAN \\ Pengujian Impak}

Pengujian ini dilakukan menggunakan alat uji impak dengan metode Charpy. Pada pengujian ini pendulum ditarik sampai dengan sudut $146^{\circ}$ dan beban pendulum yang digunakan sebesar $30 \mathrm{~kg}$. Spesimen uji yang digunakan sebanyak 10 spesimen dan setiap media pendingin adalah 2 spesimen. Tabel 1 adalah data dimensi dan hasil pengujian impak pada setiap spesimen yang telah di heat treatment dan dilakukan proses quenching dengan beberapa variasi media pendingin. 
Tabel 1. Data Dimensi dan Hasil Uji

\begin{tabular}{|c|c|c|c|c|c|c|}
\hline \multirow{2}{*}{ Media } & $\mathbf{L}$ & $\mathbf{A}$ & b & \multirow{2}{*}{$\begin{array}{c}\mathbf{A 0} \\
\left(\mathbf{m m}^{2}\right)\end{array}$} & \multirow{2}{*}{$\begin{array}{c}\mathbf{E} \\
(\mathbf{J})\end{array}$} & \multirow{2}{*}{$\begin{array}{c}\mathbf{K} \\
(\mathbf{J} / \mathbf{m} \\
\left.\mathbf{m}^{2}\right)\end{array}$} \\
\hline & \multicolumn{3}{|c|}{$(\mathrm{mm})$} & & & \\
\hline \multirow{2}{*}{$\begin{array}{c}\text { Air } \\
\text { Garam }\end{array}$} & 55 & 10 & 8 & 80 & 47.5 & 0.59 \\
\hline & 55 & 10 & 8 & 80 & 20 & 0.25 \\
\hline \multirow[b]{2}{*}{ Air } & 55 & 10 & 8 & 80 & 50 & 0.63 \\
\hline & 55 & 10 & 8 & 80 & 25 & 0.31 \\
\hline \multirow{2}{*}{ Solar } & 55 & 10 & 8 & 80 & 55 & 0.69 \\
\hline & 55 & 10 & 8 & 80 & 98.75 & 1.23 \\
\hline \multirow{2}{*}{ Oli } & 55 & 10 & 8 & 80 & 100 & 1.25 \\
\hline & 55 & 10 & 8 & 80 & 58.75 & 0.73 \\
\hline \multirow{2}{*}{ Udara } & 55 & 10 & 8 & 80 & 137.5 & 1.72 \\
\hline & 55 & 10 & 8 & 80 & 230 & 2.88 \\
\hline
\end{tabular}

Pada tabel 1 terlihat bahwa ada 2 hasil yang diperoleh dari setiap media pendingin sehingga ada nilai tertinggi dan terendah dan penulis menggunakan nilai tertinggi untuk pembahasan nilai uji impak dan nilai terendah sebagai pembanding.

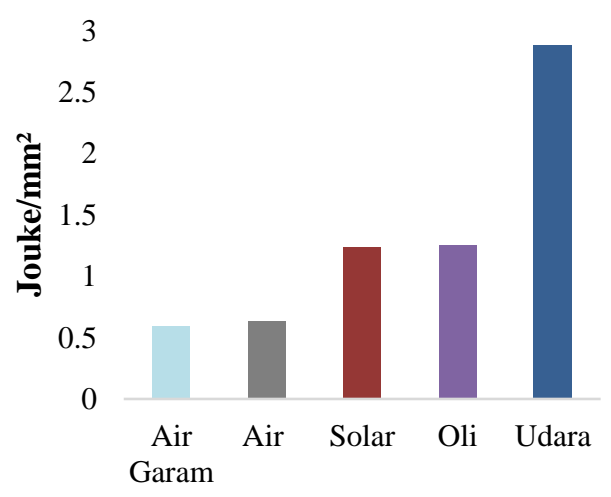

\section{Gambar 2. Nilai Pengujian Impak}

Berdasarkan pada data hasil pengujian yang telah dilakukan pada kelima spesimen uji yang telah dilakukan proses quenching dengan variasi media pendingin diperoleh bahwa spesimen yang dilakukan proses quenching dengan udara menghasilkan nilai rata-rata yang paling tinggi yaitu $2.88 \mathrm{Joule} / \mathrm{mm}^{2}$, spesimen yang dilakukan proses quenching dengan oli sebesar $1.25 \mathrm{Joule} / \mathrm{mm}^{2}$, spesimen yang dilakukan proses quenching dengan solar sebesar 1.23 Joule $/ \mathrm{mm}^{2}$, dan spesimen yang dilakukan proses quenching dengan air sebesar $0.63 \mathrm{Joule} / \mathrm{mm}^{2}$ serta spesimen uji yang menghasilkan nilai kekerasan paling rendah yaitu spesimen uji yang telah dilakukan proses quenching air garam sebesar $0.59 \mathrm{Joule} / \mathrm{mm}^{2}$.

\section{Hasil Pengujian Kekerasan}

Tabel 2 Data Hasil Uji Kekerasan

\begin{tabular}{|c|l|r|}
\hline $\begin{array}{c}\text { Media } \\
\text { Pendingin }\end{array}$ & \multicolumn{1}{|c|}{$\begin{array}{c}\text { Kode } \\
\text { Spesimen }\end{array}$} & $\begin{array}{c}\text { Hasil } \\
\text { Uji } \\
\text { (HRC) }\end{array}$ \\
\hline \multirow{2}{*}{ Air garam } & B1.1 & 62.47 \\
\cline { 2 - 3 } & B1.2 & 56.97 \\
\hline \multirow{2}{*}{ Air } & B2.1 & 56.67 \\
\cline { 2 - 3 } & B2.2 & 56.27 \\
\hline \multirow{2}{*}{ Solar } & B3.1 & 52.43 \\
\cline { 2 - 3 } & B3.2 & 52 \\
\hline \multirow{2}{*}{ Oli } & B4.1 & 49.1 \\
\cline { 2 - 3 } & B4.2 & 43.9 \\
\hline \multirow{2}{*}{ Udara } & B5.1 & 43.2 \\
\cline { 2 - 3 } & B5.2 & 41.23 \\
\hline
\end{tabular}

Pengujian ini dilakukan dengan menggunakan metode Rockwell atau yang sering disebut nilai kekerasan HRC (hardness Rockwell). Pada pengujian ini menggunakan indentor berupa bola baja berukuran 1/16". Pengujian dilakukan pada 10 sampel yang telah di heat treatment dan dilakukan proses quenching dengan beberapa media pendingin. Pada setiap spesimen uji dilakukan sebanyak 3 kali indentasi. Pada Tabel 2 menunjukkan hasil pengujian kekerasan:

Pada Tabel 2 dapat terlihat bahwa ada 2 hasil yang didapat dari setiap media pendingin sehingga ada nilai tertinggi dan terendah dan penulis menggunakan nilai tertinggi untuk pembahasan nilai uji impak dan nilai terendah sebagai pembanding. Berdasarkan pada data hasil pengujian yang telah dilakukan pada kelima spesimen uji yang telah dilakukan proses quenching dengan variasi media pendingin. Pada spesimen yang dilakukan proses quenching dengan udara menghasilkan nilai rata-rata yang paling rendah yaitu 43.2 HRC, spesimen yang dilakukan proses quenching dengan oli sebesar 49.1 HRC, spesimen yang dilakukan proses quenching dengan solar sebesar $52.43 \mathrm{HRC}$, dan spesimen yang dilakukan proses quenching dengan air sebesar 56.67 HRC serta spesimen uji yang 
menghasilkan nilai kekerasan paling tinggi yaitu spesimen uji yang telah dilakukan proses quenching air garam sebesar

62.47 HRC. Berikut adalah grafik nilai kekerasan rata- rata pada setiap spesimen pengujian:

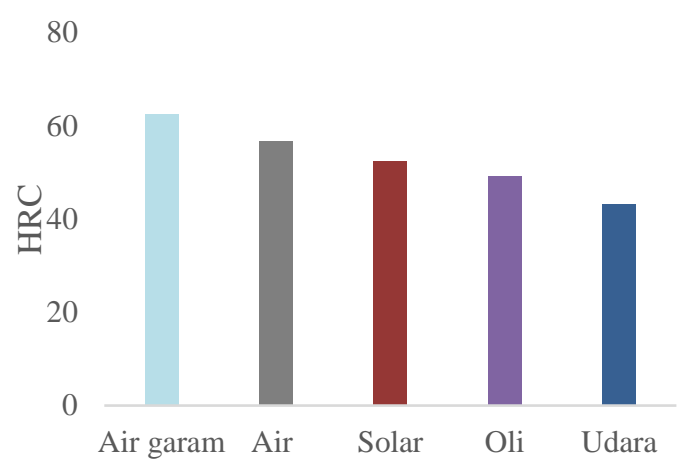

Gambar 3. Grafik Nilai Kekerasan

\section{PENUTUP}

\section{Kesimpulan}

Berdasarkan penelitian yang telah penulis lakukan mengenai pengaruh variasi media pendingin pada saat proses quenching terhadap kekerasan dan ketangguhan baja AISI 1045, dapat ditarik kesimpulan sebagai berikut:

Hasil pengujian kekerasan yang telah dilakukan menunjukkan bahwa media pendingin yang laju pendinginannya cepat dipengaruhi dari massa jenis yang tinggi sehingga diperoleh nilai kekerasan yang tinggi. Hal itu berbanding terbalik pada hasil pengujian impak. Hal ini terbukti bahwa nilai kekerasan pada media quenching udara memperoleh nilai kekerasan paling rendah yaitu sebesar 43.2 HRC dan air garam yang paling tinggi yaitu sebesar $62.47 \mathrm{HR}$.

Hasil pengujian impak yang telah dilakukan menunjukkan bahwa media pendingin yang laju pendinginannya cepat dipengaruhi dari massa jenis yang tinggi sehingga nilai impak yang diperoleh rendah. Hal ini terbukti bahwa nilai impak pada media quenching air garam yang paling rendah yaitu sebesar 0.59 Joule $/ \mathrm{mm}^{2}$ dan yang tertinggi pada udara sebesar 2.88 Joule $/ \mathrm{mm}^{2}$.

\section{Saran}

Pada saat proses pengelasan kebersihan spesimen harus sangat diperhatikan karena hal itu bisa terjadi cacat yang berupa terak (kotoran).

\section{DAFTAR PUSTAKA}

Dieter, G. E. (1988). Evaluation of workability: introduction. ASM Handbook.

Duniawan, A. (2014). Pengaruh Kecepatan Arus Pengelasan Dan Panas Masuk Terhadap Sifat Mekanis Logam Las Pada Pengelasan Saw Baja Karbon Astm a 29. Jurnal Teknologi Technoscientia, 7(1), $1-9$.

Priyanto, I. (2017). Pengaruh temperatur media pendingin (air, collant, oli) pada pengelasan GMAW terhadap struktur mikro, kekuatan tarik dan kekerasan pada baja st. 1-59.

Purwanto, H. (2011). Analisa Quenching Pada Baja Karbon Rendah Dengan Media Solar. Momentum, 7(1), 36-40.

Siswanto. (2011). Konsep Dasar Teknik Las (Teori dan Praktik). P.T. Prestasi Pustakarya.

Sultoni, S., Finahari, N., \& Sahbana, M. A. (2020). ANALISA PENGARUH VARIASI MEDIA PENDINGIN AIR DAN OLI PADA SAMBUNGAN LAP JOINT TERHADAP SIFAT MEKANIK MENGGUNAKAN LAS SMAW .... PROTON. http://publishingwidyagama.ac.id/ejournalv2/index.php/proton/article/viewFile/123 $0 / 1006$

Widharto, S. (2007). Menuju juru las tingkat dunia. Cetakan Pertama. PT Pradnya Paramita. Jakarta.

Wiryosumarto, H., \& Okumura, T. (2008). Teknologi Pengelasan Logam. Jakarta: Pradnya Paramita.

Yusman, F. (2018). Pengaruh Media Pendingin Pada Proses Quenching Terhadap Kekerasan dan Struktur Mikro Baja AISI 1045. digilib.unila.ac.id. http://digilib.unila.ac.id/id/eprint/30593 